\title{
Dinamika Kesetaraan Gender dalam Kehidupan Politik Di Indonesia \\ Wery Gusmansyah
}

\author{
IAIN Bengkulu \\ Jl. Raden Fatah Pagar Dewa Kota Bengkulu
}

\begin{abstract}
Dynamics Of Gender Equality in the Indonesian Political. In Indonesia, the issue of gender equality has lately become an endless issue and is still striving to continue to be championed both at the executive and legislative levels. The issue of gender equality includes substantive understanding of the gender perspective policy itself. Therefore, the gender movement then became mainstream in developing countries including Indonesia. In the process of democratization, the issue of greater women's political participation, representation and the issue of accountability is an absolute requirement for the realization of a more meaningful democracy in Indonesia. A meaningful democracy is democracy that pays attention to and fights for the interests of the majority of Indonesia's population consisting of women. The idea that politics is not territory for women is an idea that has always been echoed for centuries, and it is indeed very effective to restrict women from entering this region. Public and private terminology that is closely related to the concept of gender, gender roles, and stereotypes, has created inequality and injustice between women and men. The most obvious result of such a political situation is the marginalization and exclusion of women from formal political life. For this reason, various efforts are needed to fight for gender equality in political life, which in the future is expected to provide a change of view on patriarchal culture for the people, so that the possibility of elected female political leaders will be equal to the possibility of elected male political leaders. So that gender equality in the political world will progress and the side effects for the progress of efforts to eradicate corruption can be immediately.
\end{abstract}

Keyword: Gender and Politic

Abstrak: Di Indonesia, isu kesetaraan gender akhir-akhir ini menjadi isu yang tidak ada habisnya dan masih berusaha terus diperjuangkan baik di tingkat eksekutif maupun legislatif. Permasalahan tentang kesetaraan gender ini 
mencakup substantif pemahaman tentang kebijakan perspektif gender itu sendiri. Oleh karenanya, gerakan gender kemudian menjadi arus utama di negara-negara berkembang termasuk di Indonesia. Dalam proses demokratisasi, persoalan partisipasi politik perempuan yang lebih besar, reperesentasi dan persoalan akuntabilitas menjadi persyaratan mutlak bagi terwujudnya demokrasi yang lebih bermakna di Indonesia. Demokrasi yang bermakna adalah demokrasi yang memperhatikan dan memperjuangkan kepentingan mayoritas penduduk Indonesia yang terdiri dari perempuan. Ide bahwa politik bukan wilayah bagi perempuan adalah ide yang selalu didengungkan selama berabad-abad, dan ternyata memang sangat efektif untuk membatasi perempuan untuk tidak memasuki wilayah ini. Terminologi publik dan privat yang erat kaitannya dengan konsep gender, peran gender, dan stereotype, telah menciptakan ketidaksetaraan dan ketidakadilan di antara perempuan dan laki-laki. Akibat yang paling jelas dari situasi politik seperti itu adalah marjinalisasi dan pengucilan perempuan dari kehidupan politik formal. Untuk itu, diperlukan berbagai upaya untuk memperjuangkan kesetaraan gender dalam kehidupan politik, yang nantinya diharapkan akan memberikan perubahan pandangan tentang budaya patriakhi bagi masyarakat, sehingga kemungkinan terpilihnya peminpin politik perempuan akan sama dengan kemungkinan terpilihnya peminpin politik laki-laki. Sehingga kesetaraan gender dalam dunia perpolitikan akan semakin maju dan efek sampingnya untuk kemajuan usaha pemberantasan korupsi bisa segera dirasakan.

\section{Kata Kunci: Gender dan Politik}

\section{Pendahuluan}

Dilihat dari latar belakang historisnya, konsep kesetaraan gender menurut Rowbotham sebenarnya lahir dari pemberontakan kaum perempuan di negara-negara barat akibat penindasan yang dialami mereka selama berabadabad lamanya. Sejak zaman Yunani, Romawi, Abad
Pertengahan (the Middle Ages), dan bahkan pada "abad pencerahan" sekali pun, barat menganggap wanita sebagai makhluk inferior, manusia yang cacat, dan sumber dari segala kejahatan atau dosa. Hal ini pun kemudian memunculkan gerakan perempuan barat menuntut hak dan kesetaraan perempuan dalam bidang 
ekonomi dan politik yang pada akhirnya dikenal dengan sebutan feminis. Kelahiran "feminisme" dibagi menjadi tiga gelombang,yakni feminisme gelo mbang pertama yang dimulai dari publikasi Mary Wollstonecraft berjudul "Vindication of the Rights of Women" pada tahun 1972, yang menganggap kerusakan psikologis dan ekonomi yang dialami perempuan disebabkan oleh ketergantungan ekonomi pada laki-laki dan peminggiran perempuan dari ruang publik. Setelah itu, muncul feminisme gelombang kedua dengan doktrinnya yang memandang perbedaan gender sengaja diciptakan untuk memperkuat penindasan terhadap perempuan. Pada gelombang kedua inilah dimulai gugatan perempuan terhadap institusi pernikahan, keibuan (motherhood), hubungan lawan jenis (heterosexual relationship) dan secara radikal mereka berusaha mengubah setiap aspek dari kehidupan pribadi dan politik. Terakhir adalah feminisme gelombang ketiga yang lebih menekankan kepada keragaman (diversity), sebagai contoh ketertindasan kaum perempuan heteroseksual yang dianggap berbeda dengan ketertindasan yang dialami kaum lesbi dan sebagainya. ${ }^{1}$

\section{A. Permasalahan Kesetaraan Gender di Indonesia}

Pada dasarnya semua orang sepakat bahwa perempuan dan laki-laki berbeda. Namun, gender bukanlah jenis kelamin lakilaki dan perempuan sebagai pemberian Tuhan. Gender lebih ditekankan pada perbedaan peranan dan fungsi yang ada dan dibuat oleh masyarakat. Dalam realitas kehidupan telah terjadi perbedaan peran sosial laki-laki dan perempuan yang melahirkan perbedaan status sosial di masyarakat, di mana laki-laki lebih diunggulkan dari perempuan melalui konstruksi sosial.

Perbedaan gender antara laki-laki dan perempuan ditentukan oleh sejumlah faktor yang ikut membentuk, yang kemudian 
disosialisasikan, diperkuat, bahkan dibentuk melalui sosial atau kultural, dilanggengkan oleh interpretasi agama dan mitosmitos. Perbedaan jenis kelamin sering dipergunakan masyarakat untuk membentuk pembagian peran (kerja) laki-laki dan perempuan atas dasar perbedaan tersebut. Akibatnya terjadilah pembagian peran gender yaitu peran domestik dan peran publik. Peran domestik cenderung tidak menghasilkan uang, kekuasaan, dan pengaruh. Peran ini lebih banyak diserahkan kepada kaum perempuan, sedangkan peran publik yang menghasilkan uang, kekuasaan dan pengaruh diserahkan kepada kaum laki-laki. Akibat pembagian kerja yang tidak seimbang melahirkan ketimpangan peran laki-laki dan perempuan yang berakibat ketidakadilan gender yang merugikan perempuan. Di Indonesia, ketimpangan gender terlihat dari segala aspek antara lain dalam lingkungan keluarga, kependudukan, pendidikan, ekonomi, pekerjaan, dan dalam pemerintahan. Perbedaan peran antara lakilaki dan perempuan yang tidak seimbang ini juga sangat dipengaruhi oleh budaya dan kultural masyarakat Indonesia yang terdiri dari banyak etnis dan suku. Setiap masyarakat suku di Indonesia mempunyai ciri khas tersendiri dalam memaknai peran gender di negara ini. Di Indonesia, isu kesetaraan gender akhir-akhir ini menjadi isu yang tidak ada habisnya dan masih terus diperjuangkan baik di tingkat eksekutif maupun legislatif. Permasalahan tentang kesetaraan gender ini mencakup substantif pemahaman tentang kebijakan perspektif gender itu sendiri. Peningkatan kesadaran dan pemahaman itu, harus dibarengi dengan adanya keterwakilan perempuan-perempuan 
dalam lembaga-lembaga
negara, terutama lembaga
pembuat Mengingat perempuan masih saja mengalami ketimpangan di bidang pendidikan, sosial, politik, dan ekonomi hanya karena perkembangan pengetahuan masyarakat Indonesia tentang gender itu sendiri masih sangat lambat. Meskipun perempuan ditempatkan pada peran domestik di lingkungan keluarga. Namun posisi perempuan Indonesia di lingkungan keluarga selalu dinomorduakan. Karena berperan sebagai pencari nafkah, posisi kepala rumah tangga pada umumnya akan diserahkan kepada lakilaki/suami, kecuali jika perempuan tersebut adalah seorang janda atau tidak ada laki-laki dalam suatu keluarga. $^{2}$

Selama ini, pemahaman masyarakat Indonesia merekonstruksi bahwa secara kodrat, perempuan lemah dan lakilaki kuat, sehingga untuk menjadi pemimpin dalam sebuah keluarga tetap diserahkan kepada laki-laki. Hal ini menunjukkan dominasi laki-laki pada peran domestik. Keadaan tersebut menyebabkan posisi perempuan sarat dengan pekerjaan yang beragam, dalam waktu yang tidak terbatas, seperti memasak, mengurus rumah, mengurus anak, dan sebagainya. Pekerjaan domestik tersebut dilakukan bersama-sama dengan fungsi reproduksi. Penempatan perempuan pada tugas domestik sepenuhnya mengakibatkan potensi perempuan untuk melakukan hal produktif menjadi berkurang. Memang, sejak awal berdirinya Negara Kesatuan Republik Indonesia, Pemerintah secara resmi telah menganut dan menetapkan kesepakatan atas persamaan antara perempuan dan lakilaki sebagaimana termuat dalam UUD 45 Pasal 27. Namun demikian, dalam perkembangannya, beberapa UU yang selama ini berlaku 
di Indonesia, disadari mempunyai arti yang masih diskriminatif terhadap perempuan. Seperti dalam UU mengenai sistem pengupahan tenaga kerja perempuan, tunjangan keluarga dan tunjangan kesehatan-perempuan

dianggap lajang sehingga suami dan anak-anak tidak mendapatkan tunjangan sebagaimana yang diterima pekerja laki-laki.

Ketentuan ini termuat dalam Surat Edaran Menteri Tenaga Kerja No. 7 Tahun 1990 tentang Upah, PP No. 37 Tahun 1967 tentang Sistem Pengupahan di lingkungan perusahaan negara. Peraturan Menteri Pertambangan No.2/P/M/1971, Peraturan Menteri Pertanian No.K440/01/2/1984 dan No.01/GKKU/3/1978 dan SE Menaker No.4/1988 tentang tunjangan kesehatan, serta pasal 8 UU No.7/1983, pasal 4 Peraturan Menteri Keuangan No. 947/KMK/04/1983 dan Pasal 8 UU No. 10/1994 tentang prosedur memperoleh NPWP. Selain itu, berdasarkan data Komnas perempuan tahun 2012, telah teridentifikasi ada sekitar 282 peraturan daerah yang diduga bias gender. Sejumlah peraturan perundangan tersebut tidak mampu mengakomodir kesetaraan gender yang telah dijamin oleh UUD. Padahal, kesetaraan gender dimaknai sebagai kesamaan kondisi bagi laki-laki dan perempuan untuk memperoleh kesempatan serta hak-haknya sebagai manusia dalam berperan dan berpartisipasi dan menerima manfaat pembangunan di segala bidang kehidupan. ${ }^{3}$

\section{B. Kesetaraan Gender di Dunia Perpolitikan Indonesia}

Politik pada hakekatnya adalah upaya untuk merebut peran kekuasaan, termasuk akses dan kontrol dalam pengambilan keputusan. Hingga saat ini, kondisi perpolitikan yang ada di 
Indonesia masih sangatlah didominasi oleh laki-laki, baik di tingkat yang paling sederhana yaitu keluarga, tingkat masyarakat hingga tingkat politik formal. Gender menjadi isu yang banyak dibicarakan seirama dengan perkembangan akses perpolitikan bagi perempuan. Melalui akses perpolitikan, maka kesadaran untuk membincang relasi gender di dalam kehidupan masyarakat menjadi semakin mengedepan. Kesetaraan gender sebagaimana yang diketahui adalah produk impor dari negeri barat tentang adanya tuntutan untuk keseimbangan peran di dalam relasi gender tersebut. Pembicaraan gender di Indonesia banyak dilakukan di tahun 1980-an. Melalui program dari Non Governmental Organization (NGO) lokal yang bekerja sama dengan NGO internasional, maka banyak penyadaran tentang relasi gender yang dilakukan di Indonesia.

Banyak perbincangan dan pelatihan dengan tujuan untuk menyadarkan tentang relasi gender. Jadi, yang dilakukan adalah melakukan pelatihan tentang urgensi gender mainstreaming pada masyarakat negara sedang berkembang. Di dunia internasional, banyak NGO yang bergerak di dunia ketiga, misalnya NGO dari Belanda, Jerman, Inggris, dan juga Australia. Banyak program yang diusung, misalnya tentang kesetaraan pendidikan, sosial, dan politik yang disinergikan dengan NGO lokal Indonesia yang juga bergerak di bidang ini. Oleh karenanya, gerakan gender kemudian menjadi arus utama di negara-negara berkembang termasuk di Indonesia. Di dunia politik, memang dominasi lelaki masih nampak. Misalnya jika kita secara kuantitatif berhitung, berapa banyak perempuan yang memasuki kawasan pimpinan di perpolitikan Indonesia. Pertanyaan-pertanyaan ini 
yang memang masih menjadi ganjalan di dalam kerangka untuk kesetaraan gender. Namun demikian, di akhirakhir ini, akses perempuan di dalam politik memang sudah mulai tampak dengan semakin banyaknya keterlibatan perempuan di dalam politik praktis. Sekarang semakin banyak perempuan di dunia legislatif, birokrasi, dan juga jabatanjabatan politik lain. Ada beberapa bupati perempuan yang terdapat di Indonesia, demikian pula gubernur. Bahkan ada bupati perempuan yang bisa menjabat dua kali periode, demikian pula gubernur. Tidak terhitung yang berlama-lama di parpol dan kemudian berlanjut di lembaga legislatif. ${ }^{4}$

Semakin terbuka akses keterbukaan politik, maka tentu akan semakin banyak perempuan yang akan bisa berkompetisi dengan kaum lelaki di dalam pentas publik. Oleh karena itulah pemberian kuota kepada perempuan di dalam representasi politik tentulah tidak penting. Meskipun begitu, saat ini hak-hak politik bagi perempuan sudah banyak diakui. Namun adanya hakhak tersebut tidak menjamin adanya sistem politik yang demokratis di mana asas partisipasi, representasi, dan akuntabilitas diberi makna sesungguhnya. Adanya keterwakilan perempuan di dalamnya, dan berbagai kebijakan yang muncul yang memiliki sensitivitas gender tidak serta merta terwujud meskipun hak politik perempuan sudah diakui. Perempuan sebagai warga negara seharusnya dapat berpartisipasi secara mandiri dalam proses demokrasi ini. Selama ini di Indonesia, kita mendapati bahwa sebagian besar perempuan bahkan belum dapat membuat pilihan politiknya secara mandiri. Pilihan politik perempuan banyak dipengaruhi atau bahkan ditentukan oleh suami, atasan, teman, atau keluarga. 
Bukti-bukti empiris sudah menunjukkan bahwa kesetaraan gender sudah bukan masalah di negeri ini. Hanya saja yang memang perlu diperjuangkan adalah bagaimana agar perempuan semakin berdaya di dalam pengembangan SDM terutama melalui pendidikan, sehingga ke depan peluang untuk memasuki dunia politik akan semakin nyata. ${ }^{5}$

\section{Pentingnya}

Kesetaraan

Gender dalam Kehidupan Politik

Pendidikan politik adalah suatu aktivitas yang bertujuan untuk membentuk dan menumbuhkan orientasiorientasi politik pada setiap individu maupun kelompok. Proses pendidikan politik dilakukan agar masyarakat luas dapat menjadi Warga Negara Indonesia yang sadar dan menjunjung tinggi akan hak dan kewajibannya dalam kehidupan bermasyarakat berbangsa, dan bernegara, serta memperhatikan keadilan dan kesetaraan gender. Hal ini ditekankan karena pada realitasnya, masih dirasakan adanya kesenjangan antara peranan yang dilakukan oleh kaum pria dan perempuan pada berbagai peran, utamanya pada peran-peran publik. Oleh karena itu, peningkatan peran perempuan dalam pembangunan yang berwawasan gender sebagai bagian integral dari pembangunan nasional, mempunyai arti yang penting dalam upaya untuk mewujudkan

kemitrasejajaran yang harmonis antara pria dan perempuan agar dapat terwujud kesetaraan dan keadilan gender dalam berbagai kegiatan khususnya bidang politik. Perempuan mempunyai makna yang sangat penting untuk memberikan pemahaman dan menyatukan persepsi tentang pentingnya pembangunan demokrasi yang sehat, adil dan realistis. Oleh karena itu, pengembangan pendidikan politik perempuan, perlu 
ditingkatkan baik dari segi organisasional maupun pemantapan pilar-pilar demokrasi melalui lembaga legislatif, eksekutif maupun yudikatif yang aspiratif dan pro terhadap kepentingan perempuan.

Kondisi semacam ini perlu mendapat perhatian khusus, untuk itulah salah satu hal yang perlu ditangani adalah masalah pendidikan politik bagi kaum perempuan, sehingga dengan tumbuh berkembangnya kesadaran politik dikalangan perempuan, mereka diharapkan mampu memanfaatkan kesempatan dan peluang yang ada sesuai potensi yang dimiliki dan sesuai ketentuan peraturan perundang-undangan yang berlaku. Kebijakan khusus afirmasi (Affirmative Action) harus segera diubah dengan srategi Pengurus Utamaan Gender (PUG) di semua bidang kehidupan, khususnya di semua lini dan strata untuk mempercepat persamaan akses, partisipasi, kontrol, serta manfaat yang sama antara perempuan dan laki-laki. Berdasarkan Inpres Nomor 9 tahun 2000, eksekutif hanya mengikat untuk melaksanakan PUG. Oleh karena itu, perlu ditingkatkan jumlah kebijakan pelaksanaan PUG yang akan mengikat seluruh pemangku kepentingan, baik pemerintah, penyelenggara pemilu, dan partai politik sebagai pilar demokrasi untuk mendorong pemenuhan Hak Asasi Manusia (HAM) perempuan di bidang politik melalui peningkatan keterwakilan perempuan dalam pengambil kebijakan.

Gerakan perempuan dan pemerhati masalah perempuan, melakukan upaya yang sangat keras memperjuangkan masuknya kuota sebesar $\quad 30 \%$ keterwakilan perempuan sebagai jumlah minimal dalam paket UU politik dari hulu ke hilir.

Menteri

Pemberdayaan Perempuan 
Jurnal Hawa Vol. I No. I Januari-Juni 20IG

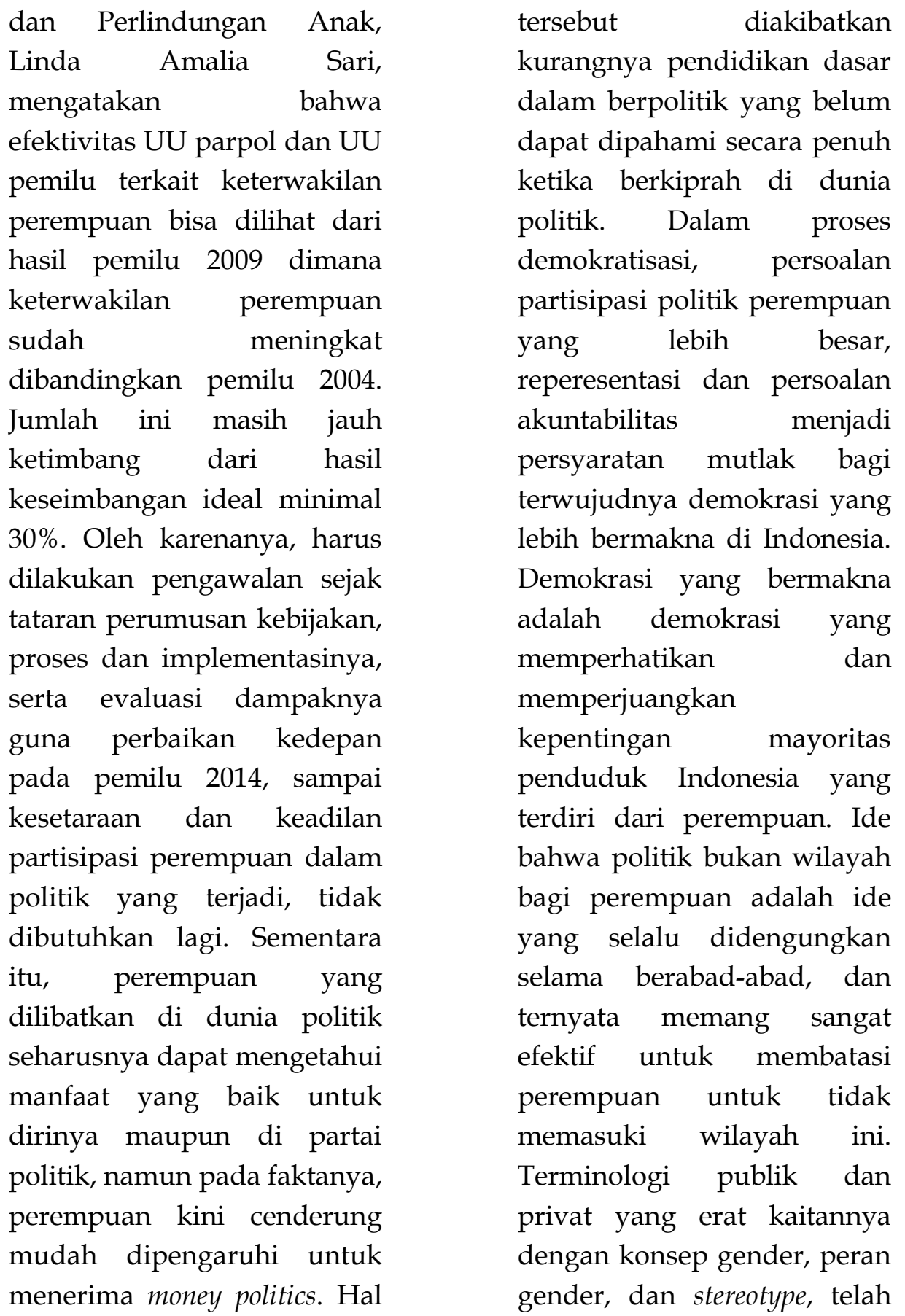


menciptakan ketidaksetaraan dan ketidakadilan di antara perempuan dan laki-laki. Akibat yang paling jelas dari situasi politik seperti itu adalah marjinalisasi dan pengucilan perempuan dari kehidupan politik formal. Ini artinya, keberadaan perempuan dalam kehidupan politik formal di banyak tempat memperlihatkan gambaran yang tidak menggembirakan. Akar dari semua persoalan tersebut adalah budaya patriarki yang menghambat semua ruang gerak perempuan di semua bidang, termasuk bidang politik. Demokrasi berkaitan erat dengan politik. Konsep demokrasi berasal dari istilah politik yang berarti pemerintahan oleh rakyat. Di dalamnya terkandung makna "dari rakyat, oleh rakyat, dan untuk rakyat". Dalam terminologi politik yang bias gender, untuk waktu yang lama, pengertian partisipasi " dari rakyat, oleh rakyat, dan umtuk rakyat" hanya diartikan secara terbatas hanya untuk beberapa kalangan tertentu dalam masyarakat, dan tentu saja tidak termasuk perempuan di dalamnya. Keterwakilan perempuan adalah untuk menyuarakan kepentingan perempuan. Pada titik ini, yang banyak diabaikan oleh banyak kalangan, bahkan oleh kalangan perempuan sendiri, adalah bahwa kepentingan-kepentingan perempuan memang lebih baik disuarakan oleh perempuan sendiri karena mereka sesungguhnya paling mengerti kebutuhan perempuan. Dalam kerangka demokrasi yang representative, pandangan dari kelompok yang berbeda harus dipertimbangkan dalam memformulasikan keputusan dan kebijakan yang akan dibuat. Mempertimbangkan kepentingan perempuan dan melibatkan laki-laki dan perempuan dalam proses pembuatan kebijakan adalah dasar dari kerangka demokrasi yang mendorong 
Jurnal Hawa Vol. I No. I Januari-Juni 20IG

ke arah kesetaraan dan keadilan gender.

D. Upaya Memperjuangkan Kesetaraan Gender dalam Kehidupan Politik

Pada dasarnya, kuota $30 \%$ yang diberikan untuk keterlibatan perempuan dalam politik dan keterwakilan perempuan dalam parlemen yang diamanatkan oleh Undangundang No. 10 tahun 2008 tentang Pemilu Legislatif dan Undang-undang No. 2 tahun 2008 tentang Partai Politik (Parpol), masih sangat jauh dengan kenyataannya. Walau sejatinya angka 30\% ditinjau dengan hitungan statistik berdasarkan jumlah masih dinilai tidak adil. Namun sebagian kalangan perempuan yang lain menyambut hal ini sebagai langkah maju untuk memberi gerak bagi perekrutan kaum perempuan dalam langkah politiknya. Karena selama ini perempuan hanya berjumlah $12 \%$ saja yang berkiprah dalam ruang sidang di
Senayan. Merupakan fenomena baru dan menyegarkan dalam perkembangan sistem demokrasi di Indonesia, meskipun dalam tataran yang relatif kecil dan sederhana, tetapi masih banyak harapan dan peluang yang bisa dilalui oleh para perempuan dalam partisipasinya untuk mensosialisasikan dan mengimplementasikan undang-undang tersebut sekaligus sebagai penghargaan terhadap pengorbanan dan perjuangan perempuan yang selama terpinggirkan oleh sistem. Karena pada kesempatan kali ini, publik akan memberikan penilaian langsung terhadap partai-partai politik peserta pemilu yang mempunyai kepedulian terhadap perjuangan serta potensipotensi perempuan, bahkan ada semacam kecaman dari berbagai lembaga swadaya masyarakat (LSM) atau organisasi-organisasi kemasyarakatan perempuan lainnya, untuk tidak memilih 
gambar partai yang tidak memperhatikan kepentingan perempuan atau dengan tidak merealisasikan UndangUndang tentang keterwakilan perempuan. ${ }^{6}$

Keterwakilan perempuan menjadi penting karena jumlah perempuan dalam panggung politik masih sangat rendah, berada dibawa standar, sehingga posisi dan peran perempuan dalam lembaga legislatif, terlebih jabatan eksekutif sebagai pengambil dan penentu kebijakan masih minim. Hal ini menunjukkan bahwa keberadaan perempuan masih belum diperhitungkan. Dengan adanya dorongan untuk keterwakilan perempuan yang 30\% di parlemen saat pemilu 2009 tersebut, seperti diamanatkan UU No. 10 tahun 2008, walaupun belum ada affirmative action yang memberikan previlage tertentu, sehingga memberikan syarat yang lebih mudah bagi caleg perempuan dari pada caleg laki-laki, namun hasil dari pemilu tersebut sudah menunjukkan keterwakilan yang meningkat dari pemilu sebelumnya, yaitu untuk DPR RI 18\% dari sebelumnya yang hanya $12 \%$ dan untuk keterwakilan di DPD agak lebih tinggi dari pada keterwakilan di DPR, yaitu $27,3 \%$ dari sebelumnya $18,8 \%$. Berdasarkan data tersebut di atas, kurang adanya pengakuan terhadap pentingnya peran perempuan dalam proses politik, telah terbuktikan dengan kurang terakomodirnya

permasalahan perempuan dalam perencanaan pembangunan, meskipun sejak lama sudah dikampanyekan dalam isu gender mainstreaming tentang perempuan sebagai bagian dan sasaran dalam pembangunan pada tahun 1974 dengan menggunakan pendekatan "Women In Development Approach (WID)". Hal ini dikarenakan konsep gender dalam pembangunan masih belum diterjemahkan 
dengan baik oleh semua elemen pembangunan baik secara teoritis maupun aplikatif. Sehingga hasil-hasil pembangunan masih berpihak pada kelompokkelompok tertentu.dan menjadi bias gender. Adapun upaya-upaya untuk mencapai penyetaraan dan keadilan gender terus dilakukan oleh aktivis perempuan, pada tahun 1980an, melalui pendekatan "Gender And Development Aproach (GAD)". Pendekatan ini tidak lagi melihat perempuan dan laki-laki dari perbedaan biologis, akan tetapi memandang laki-laki dan perempuan secara sosial dan struktural dapat berpartisipasi dalam proses kehidupan, terutama partisipasi dalam kehidupan di ranah politik dan publik. Partisipasi antara laki-laki dan perempuan dalam kehidupan berpolitik merupakan salah satu prinsip perjuangan para aktivis perempuan, sampai diamanatkan dalam konvensi penghapusan segala bentuk diskriminasi terhadap perempuan yang kemudian diadopsi oleh sidang umum PBB tahun 1979 yang ditetapkan pada tahun 1981. Pemerintah Indonesia sendiri juga telah meratifikasi melalui Undang-Undang Republik Indonesia no. 7 tahun 1984 pada tanggal 24 juli 1984 melalui lembar negara no. 29 tahun 1984. Meskipun demikian, sampai saat ini perjuangan menuju kesetaraan dan keadilan masih belum optimal karena adanya diskriminasi secara struktural dan kelembagaan yang masih kuat dalam kehidupan masyarakat. Pendiskriminasian semacam ini semakin melemahkan sumber daya perempuan terlebih ketika para perempuan tidak mempunyai keinginan untuk merubah dan melakukan pembenahanpembenahan sejak dini.

Untuk itu, adapun upaya untuk memperjuangkan kesetaraan gender dalam kehidupan 
politik, yakni pertama, harus diusahakan adanya peraturan atau UU tentang pemilu, pilkada, dan partai politik yang mencantumkan perihal affirmative action terhadap keterwakilan perempuan dengan memberikan previlage tertentu kepada keterwakilan perempuan, sehingga dengan adanya affirmative action, diharapkan keterwakilan perempuan akan meningkat dan sesuai harapan. Kedua, diperlukan adanya usahausaha peningkatan pendidikan bagi perempuan secara terus menerus. Karena dengan adanya peningkatan taraf pendidikan bagi kaum perempuan, maka akan meningkatkan kompetensi dan daya saing kaum perempuan di bidang politik. Ketiga, diperlukan adanya pencerahan dan pendidikan politik yang terus-menerus kepada masyarakat luas, bisa dilakukan oleh lembaga swadaya masyarakat, ormas, ataupun oleh lembagalembaga lain, tentang unggulnya pemimpin politik perempuan. Dengan usaha itu diharapkan akan memberikan perubahan pandangan tentang budaya patriarki bagi masyarakat, sehingga kemungkinan terpilihnya pemimpin politik perempuan akan sama dengan kemungkinan terpilihnya pemimpim politik laki-laki. Sehingga kesetaraan gender dalam dunia perpolitikan akan semakin maju dan efek sampingnya untuk kemajuan usaha pemberantasan korupsi bisa segera dirasakan. ${ }^{7}$

\section{E. Kesimpulan}

1. Perbedaan gender antara laki-laki dan perempuan ditentukan oleh sejumlah faktor yang ikut membentuk, yang kemudian disosialisasikan, diperkuat, bahkan dibentuk melalui sosial atau kultural, dilanggengkan oleh interpretasi agama dan mitos-mitos. Perbedaan jenis jenis kelamin sering dipergunakan masyarakat untuk 
pembagian peran (kerja) lakilaki dan perempuan atas dasar perbedaan tersebut. Akibatnya terjadilah pembagian peran gender yaitu peran domestik dan peran publik.

2. Politik pada hakekatnya adalah upaya untuk merebut peran kekuasaan, termasuk akses dan kontrol dalam pengambilan keputusan. Hingga saat ini, kondisi perpolitikan yang ada di Indonesia masih sangatlah didominasi oleh laki-laki, baik di tingkat yang paling sederhana yaitu keluarga, tingkat masyarakat hingga tingkat politik formal. Gender menjadi isu yang banyak dibicarakan seirama dengan perkembangan akses perpolitikan bagi perempuan.

3. Keterwakilan perempuan menjadi penting karena jumlah perempuan dalam panggung politik masih sangat rendah, berada dibawa standar, sehingga posisi dan peran perempuan dalam lembaga legislatif, terlebih jabatan eksekutif sebagai pengambil dan penentu kebijakan masih minim.

\section{Daftar Pustaka}

Adhyepanritalopi. 2013. Menakar RUU Kesetaraan Gender.

Bawaslu. 2015. Pentingnya Kesetaraan Gender Dibidang Politik.

Hidayati, Khozanah. 2010. Semangat Kartini dalam Perjuangan Kesetaraan Gender Politik.

Syam, Nur. 2013. Membincang Gender di Indonesia.

http://www.bawaslu.go.id/berit a/all//tahun/2013/bulan/02 /tanggal/05/id/4158/ (accessed Maret 4, 2018).

http:/ / nursyam.sunanampel.ac.id/?p=2800 (accessed April 4, 2018).

http://hukum.kompasiana.com/ 2013/05/04/menakar-ruukesetaraan-gender 557056.html (accessed April 4, 2018). 
http:// politik.kompasiana.com/ 2010/04/21/semangatkartini-dalam-perjuangankesetaraan-gender-politik121878.html ( accessed April 4, 2018 ).

http:// wartawarga.gunadarma.a c.id/2010/04/kesetaraangender$\%$ E2 $\% 80 \% 9$ Cperempuan-danpolitik-diindonesia\%E2\%80\%9D/ (accessed Mei 2, 2018).

Wartawarga. 2017. Kesetaraan Gender? "Perempuan dan Politik di Indonesia".

\section{Refrensi}

1 Khozanah Hidayati, 2010:

12

2http://hukum.kompasia na.com/2013/05/04/menakarruu-kesetaraan-gender557056.html (accessed April 4, 2018).

3http://hukum.kompasia na.com/2013/05/04/menakarruu-kesetaraan-gender557056.html (accessed April 4, 2018)

${ }^{4}$ Nur Syam, 2013: 56a

${ }^{5}$ Nur Syam, 2013:70-71b

${ }^{6}$ http://wartawarga.guna darma.ac.id/2010/04/kesetaraan -gender-
$\%$ E2\%80\%9Cperempuan-danpolitik-diindonesia\% $\% 2 \% 80 \% 9 \mathrm{D} /$ (accessed April 4, 2018). 7Wartawarga. 2017:2 